Meta

Journal des traducteurs

Translators' Journal

\title{
The Return of Sense on the Scene of Translation Studies in the Light of the Cognitive Blending Theory
}

\section{Atin Fougner Rydning}

Volume 50, numéro 2, avril 2005

Processus et cheminements en traduction et interprétation Processes and Pathways in Translation and Interpretation

URI : https://id.erudit.org/iderudit/010989ar

DOI : https://doi.org/10.7202/010989ar

Aller au sommaire du numéro

Éditeur(s)

Les Presses de l'Université de Montréal

ISSN

0026-0452 (imprimé)

1492-1421 (numérique)

Découvrir la revue

Citer cet article

Fougner Rydning, A. (2005). The Return of Sense on the Scene of Translation Studies in the Light of the Cognitive Blending Theory. Meta, 50(2), 392-404. https://doi.org/10.7202/010989ar
Résumé de l'article

L'objectif du présent article est de donner un nouveau souffle au modèle de déverbalisation et de reverbalisation du sens de l'École de Paris - modèle qui consiste à représenter le sens comme une entité mentale - à la lumière de la théorie cognitive de l'intégration conceptuelle. Au moyen d'exemples puisés dans les données processuelles in vivo de deux experts-traducteurs constituées par leurs protocoles de verbalisation et leurs activités d'écriture informatisées, je décèle l'imagination et la créativité déployées pour construire le sens, avant de montrer comment le modèle cognitiviste permet de rendre compte du sens en termes de projection domaniale et de relations entre divers espaces mentaux. 


\title{
The Return of Sense on the Scene of Translation Studies in the Light of the Cognitive Blending Theory
}

\author{
ANTIN FOUGNER RYDNING \\ University of Oslo, Oslo, Norway \\ a.f.rydning@kri.uio.no
}

\begin{abstract}
RÉSUMÉ
L'objectif du présent article est de donner un nouveau souffle au modèle de déverbalisation et de reverbalisation du sens de l'École de Paris - modèle qui consiste à représenter le sens comme une entité mentale - à la lumière de la théorie cognitive de l'intégration conceptuelle. Au moyen d'exemples puisés dans les données processuelles in vivo de deux experts-traducteurs constituées par leurs protocoles de verbalisation et leurs activités d'écriture informatisées, je décèle l'imagination et la créativité déployées pour construire le sens, avant de montrer comment le modèle cognitiviste permet de rendre compte du sens en termes de projection domaniale et de relations entre divers espaces mentaux.
\end{abstract}

\begin{abstract}
The aim of this paper is to revitalize the Paris school model of deverbalization and reverbalization of sense in translation, i.e. the representation of sense as a mental image, in light of the cognitive blending theory. Through sample examples of online process data taken from the concurrent think-aloud protocols of two experienced professional translators and the keylogged files on their writing processes, I will give evidence of the imaginative and creative work pertaining to their construals of sense, before showing that the blending theory model represents sense as the result of mapping concepts into other concepts and as relations between mental spaces.
\end{abstract}

\section{MOTS-CLÉS/KEYWORDS}

sense construction, blending, conceptualization, creativity, imagination.

\section{Introduction}

The main objective of this article is to capture sense construction in translation from a cognitive point of view. The model of deverbalization in translation, closely associated to representing sense as a mental image, was introduced by Danica Seleskovitch $(1968,1975)$ more than 30 years ago, and was in the two decades which followed developed and refined by the Paris school (e.g. Delisle 1980, Lederer 1981, Seleskovitch \& Lederer 1984, 1989, 1990, Hurtado Albir 1990, Laplace 1994). Although the model intuitively appealed to translation practitioners as a representation of the translation process, and despite the fact that it laid the ground for didactics in translation and interpretation studies in the 1970's up till today, its contribution to linguistics was never fully recognized. Because the concepts of deverbalization and sense were viewed as being pre-theoretical and as lacking objectivity, they were not retained as research objects by the linguistic community. With the advent of cognitive linguistics, 
and in particular two of its most recent trends, the cognitive theory of metaphor and metonymy (CTMM) and the blending theory (BT) which seek to explain the way we think, the way we conceptualize things and events, the complex mental phenomenon of sense construction in discourse has however suddenly turned into a research object of prime interest. By providing us with the tools to represent sense as the result of mapping concepts into other concepts and as relations between mental spaces, these two theories are now in a position to give support to the pioneer model of deverbalization of sense presented by the Paris school. This turn of events seems to go hand in hand with the fact that imagination is today considered a major human cognitive ability, and as such it is now viewed as a respectable scientific phenomenon.

[...] work in a number of fields is converging toward the rehabilitation of imagination as a fundamental scientific topic, since it is the central engine of meaning behind the most ordinary mental events. (Fauconnier and Turner 2002: 15)

Cognitive linguistics has dealt in depth with conceptual metaphor for more than two decades, but has only very recently started to pay attention to conceptual metonymy. Today the two conceptual phenomena are claimed to be the two most central components of human cognition and ordinary language use (Lakoff \& Johnsen 1980, Lakoff \& Turner 1989, Gibbs 1994, Dirven \& Pörings (eds.) 2002, Panther \& Thornburg (eds.) 2003), and are thus addressed together in the CTMM. As René Dirven put it in his introduction to Metaphor and Metonymy in Comparison and Contrast: "In the beginning was the word, and then came metonymy and metaphor." (2003: 38) A common feature between the two is that both are mental mechanisms, not to be confused with their linguistic expression.

Both CTMM and BT focus on the cognitive constructions prompted by the linguistic expressions. Whereas CTMM typically addresses recurring patterns in language and aims at capturing generalizations across a variety of conventional metaphoric and metonymic expressions in order to account for entrenched conceptual relationships, BT seeks to model both novel metaphors, metonymies, synecdoches and other conceptual phenomena such as e.g. analogies and counterfactuals. BT seems to explain with more precision and detail the functioning of metaphor and metonymy in discourse. (Barcelona 2000: 7) Applied to translation, BT makes it possible to address questions in a new way such as e.g. the notion of creativity in translation and the nature of the links between sender text (ST) and target text (TT). I will here deal only with BT which I consider particularly powerful to explain novel online conceptualizations. But as metonymy is in my view the most basic mechanism in discourse - which paradoxically enough has received much less attention in cognitive linguistics than metaphor has - the focus will be on metonymic online conceptualizations. ${ }^{1}$ Through sample analyses of online process data taken from the concurrent think-aloud protocols of two professional translators with 15 years of active translation experience and the files on their writing processes recorded by the keylog program Translog, I will give evidence of the imaginative and creative work pertaining to their construals of sense. I shall then apply the BT-model in order to show that the translators' creative solutions in the target language are first and foremost of a conceptual nature. 


\section{Definition of metonymy as a conceptual entity}

The traditional definition of metonymy viewed as a conceptual entity is as follows:

Metonymy is a cognitive mechanism whereby one experiential domain is partially understood in terms of another experiential domain included in the same common experiential domain. [...] In metonymy the target domain is "highlighted," i.e. mentally activated, often with a limited discourse purpose (Lakoff 1987: 78-80), because it is this domain that is partially conceptualized by mapping onto it the source domain included in the same common domain. (Barcelona 2003: 215)

By contrast to metaphor which is based on conceptual similarity where conceptual structure from a source domain is mapped onto the target domain, such as in the following example:

(1) The phone is dead. (Lakoff \& Turner1989: 58)

where the general metaphor MACHINES ARE PEOPLE maps human death onto the failure of the machine to operate, metonymy is based on conceptual contiguity, i.e. the close association of two concepts. Contiguity relies on world knowledge (Blank 1993). A typical way of looking at metonymy is to say that: "A stands for B with which A is closely associated." In the linguistic expression:

(2) There are an awful lot of faces out there in the audience. (Lakoff \& Johnsen 1980: 8)

faces (A) stand for persons (B) with which faces (A) are closely associated. In order to distinguish between the conceptual entity and the linguistic expression, one commonly uses capital letters to designate the concept THE PART FOR THE WHOLE, where a special case of metonymy is THE FACE FOR THE PERSON.

\section{The blending theory}

Let us briefly present BT. Although BT is a framework different from that of the CTMM, it is complementary to it. BT builds on Gilles Fauconnier's work on mental spaces $(1994,1996)$, which has been developed by him and Mark Turner (Turner \& Fauconnier 1997, Fauconnier \& Turner 2003) and their associates Coulson \& Oakley (2000) and Grady (Coulson, Oakley \& Grady 1999).

BT, which is also known as the 'many-space model' or the 'conceptual integration network' contends that the construction of sense can be accounted for in terms of blending or conceptual integration which involves mental spaces. Mental spaces contain representations of the entities and relationships in any given scenario as perceived, imagined, remembered, or otherwise understood by a speaker (Coulson \& Oakley 2003). In conceptual integration as it proceeds in discourse, partial structure from two or more mental input spaces is projected and compressed in a blend, which frequently develops emergent structure of its own (represented as a square inside the circle in Fauconnier \& Turner's diagram below). A generic space which contains skeletal conceptual structure common to the input spaces licenses the projection.

(3) Fauconnier \& Turner's basic diagram (2002: 46) which illustrates the central features of conceptual integration: 


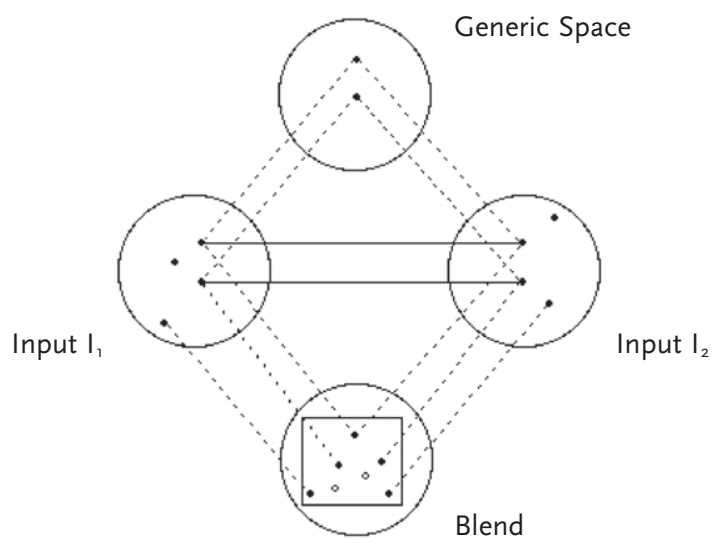

The circles represent mental spaces, the solid lines indicate the matching and crossspace mappings between the inputs, the dotted lines indicate connections between inputs and generic or blended spaces, and the solid square in the blended space represents emergent structure.

The following example will serve to show how this basic diagram can account for the sense in an utterance. When I point to the picture of my husband and say:

(4) That's Pål.

you automatically understand that the picture of my husband's face is a representation of the person Pål. I do not need to say:

(5) The face you see in the picture is that of Pål.

We understand this utterance through the use of a network where blending occurs twice. First of all we understand by metonymy that Pall's face is a representation of Pål as a person. A part of his body is a representation of the person. The salient aspect of the face (A) is used to designate the person as a whole (B). In BT-terms, we have input 1 corresponding to the element which represents the thing: in this case the face of a particular person: Pål. Input 2 corresponds to the thing represented: the whole person. In the blend, the face projected from input space 1 fuses with the whole person projected from input space 2: the face thus becomes the personal identity. This is possible because the part-whole connection between the face representing the person is compressed into one in the blend. Why the salient aspect of the face rather than other parts of the body is chosen to designate a person can be given a neurobiological explanation: "[...] faces are, through face recognition, the most salient part of the body for the purpose of maintaining identity factors" (Fauconnier \& Turner 2002: 98). It can also be given a cultural explanation:

In our culture we look at a person's face - rather than his posture or his movements to get our basic information about what the person is like. We function in terms of a metonymy when we perceive the person in terms of his face and act on those perceptions. (Lakoff \& Johnsen 1980: 37) 
As soon as we think of an input as a representation of another input, we have built a blend. The second blending occurs when structure from input space 1: the picture of Pål's face is projected with structure from input space 2: Pål's face. Because we already have the blend in which Pål's face is the same as the person Pål, the picture of Pål's face automatically becomes a representation of the person, and in the blend it is Pål. In this network Pal's face is mapped to the picture of his face. In the blend vital relations between part-whole, identity and representation which do not exist separately in the inputs are made available and are compressed into uniqueness in the blend. According to Fauconnier \& Turner "One of the most important aspects of our efficiency, insight and creativity is the compression achieved through blending." (Fauconnier \& Turner 2002: 92).

The device of recruiting information from the input spaces in order to develop new structure in the blend yielding the sense corresponds to the basic process of composition.

\section{Sample examples}

\subsection{The products}

Before describing the professional translators' online metonymic conceptualization, let us present the French original utterance as it appeared in a text on good manners at work (see appendix 1) published in the French magazine L'Express in January 2001, entitled Le retour des bonnes manières (The return of good manners):

(6) Le "BSAM" (bonjour-sourire-au revoir-merci) est enseigné partout.

The "GSGT" (good morning-smile-good bye-thank you) is taught everywhere. (My translation)

In the French original, the metonymic concept underlying the innovative acronym $B S A M$ is: THE PART FOR THE WHOLE. The two formulas of greeting: 'hello' and 'good-bye,' together with those of gratitude: 'thank you' and of friendliness: 'smile,' which we can call A, stand for 'good manners' or 'etiquette,' which we can call B. We have a relation of conceptual contiguity, where the elements in A are the salient aspects of the whole in $\mathrm{B}$, that of good manners or good breeding.

The way this French utterance was translated into Norwegian by two of the professional translators who participated in the experiment enables us to see how they understood the sense:

(7) Anne:

Det å kunne si god dag, adjø, takk og å smile på riktig vis er noe det undervises i overalt.

To be able to say good morning, good-bye, thank you and to smile in the right way is something which is taught everywhere. (My translation)

(8) Christine:

Kurs i skikk og bruk tilbys overalt.

Courses in code of conduct are offered everywhere. (My translation)

Although both translations convey the same sense as the French original, they are completely different from each other and also differ in many aspects from the original. The only linguistic element which is the same in both translations is the adverb 
'everywhere.' Both Christine and Anne have dropped the acronym in their TT. Anne's translation contains a syntactic rearrangement of the marks of courteous behavior as compared to the original metonymy. We have the infinitive 'to smile' put at the end, and coordinated to the previous infinitive clause containing the three marks of courtesy. We also have the addition of a prepositional syntagm: 'in the right way.' Christine has come up with the fixed expression skikk og bruk (customs and usage) 'code of conduct' to translate the acronym BSAM and its content. The solution 'courses are offered' corresponds here to the original est enseigné ' is taught.'

Due to space limits we shall deal here only with the translation of the novel acronym and its content in brackets: Le "BSAM" (bonjour-sourire-au-revoir-merci).

\subsection{The professional translators' online process data}

A look at the two professional translators' online process data taken from their concurrent think aloud protocols and Translog files allows us to capture their cognitive activity during the translation task. We shall start with Christine.

(9) Christine's TAP:

\begin{tabular}{|c|c|}
\hline Chritine's TAP & Chritine's TAP in English \\
\hline $\begin{array}{l}\text { Bonjour-sourire-au-revoir-merci. Ja, det er } \\
\text { altså disse BSAM. Bon chic-bon genre. Jeg } \\
\text { tror det ikke har noen hensikt å beholde } \\
\text { den. Skikk og bruk. Ja, jeg tror vi tar rett og } \\
\text { slett skikk og bruk. }\end{array}$ & $\begin{array}{l}\text { Bonjour-sourire-au-revoir-merci. O.K, here } \\
\text { we have those BSAM. Bon chic-bon genre. } \\
\text { I don't think there's any point in keeping } \\
\text { it. Good breeding. Yes, I think I'll just put } \\
\text { good breeding. }\end{array}$ \\
\hline
\end{tabular}

Christine's comment after having read aloud the content in the French acronym $B S A M$ has the immediate effect of triggering an association to bon chic-bon genre, also known under the acronym BCBG, which corresponds to "upper-class preppies" in English. After having made this association, she however discards the possibility of aligning a corresponding acronym in the target language. It seems as if she wishes to produce an acceptable translation, i.e. a translation which conforms to the norms of the target language. She has recognized a specific characteristic of French usage: the strong tendency to use acronyms. In Norwegian this use is much less widespread than in French. Her excellent understanding of the differences in norms between French and Norwegian makes her reject the idea of aligning a loan acronym in the target language.

In order to be able to show how she came up with the solution 'code of conduct,' a closer look at her TAP prior to her comments on the utterance which carries the innovative acronym BSAM is useful. On the question of how to translate the syntagm bonnes manières in the title of the text: Le retour des bonnes manières: 'The return of good manners,' Christine confesses she does not know which one of the three following synonymous solutions to choose:

(10) - gode manerer - 'good manners'

- etiquette - 'etiquette'

- skikk og bruk - 'code of conduct' 
These three solutions indicate a total control of the linguistic means at her disposal to re-express the central idea in the title in Norwegian, once she has settled for the sense. This capacity of activating alternative construals from her working memory fits well with Jean Delisle's statement on the effect that the grasping of the sense has on the translator's imaginative creativity in the phase of reformulation:

Dès lors que traduire consiste à formuler un sens et non simplement à reproduire un agencement syntaxique de mots dotés de significations virtuelles, le contexte a pour effet de décupler les moyens linguistiques dont peut disposer le traducteur pour réexprimer en langue d'arrivée le sens du message original. C'est un postulat de la textologie. Le traducteur jouit d'une "liberté créatrice," au sens où l'entend Alexandre Ljudskanov, qui le distingue du transcodeur. (Delisle 1981: 66-67 - his italics)

Christine however decides to leave out the translation of the title for the meantime. This decision can be observed both in her TAP and in her Translog file (see (11) below). In her Translog file an initial pause of 2 minutes, 19 seconds (cf. Translog segment 1), is followed by three arrows which correspond to her pressing the 'Enter' key on the keyboard three times, a sign she has left a blank. During this initial pause she makes the following comment:

(11) Christine's Translog data and TAP file:

\begin{tabular}{|l|l|l|}
\hline Christine's Translog data & Christine's TAP & Translation into English \\
\hline $\begin{array}{l}\text { 1.[Start][ResizeST] } \\
{[*: 02.19 .17]}\end{array}$ & $\begin{array}{l}\text { Le retour des bonnes manières. } \\
\text { Ja, der kan man jo enten velge } \\
\text { å beholde gode manerer eller } \\
\text { å bruke etikette kanskje } \\
\text { (kikker ut av vinduet). Jeg tror } \\
\text { jeg lar tittelen stå foreløpig og } \\
\text { begynner litt lenger ned. }\end{array}$ & $\begin{array}{l}\text { Le retour des bonnes manières. } \\
\text { O.K. Here I can choose } \\
\text { between keeping good } \\
\text { manners or using etiquette } \\
\text { (looks out of the window). I } \\
\text { think I'll leave out the title for } \\
\text { the mean time and start a } \\
\text { little further down }\end{array}$ \\
\hline
\end{tabular}

After a new pause of 1 minute, 1 second (cf. Translog segment 2 in (12) below), she writes down the three first letters of the word etikette, then pauses again for 8 seconds (cf. Translog segment 3) before writing the rest of the word (cf. Translog segment 4). This very first word in her translation corresponds to the anaphoric pronoun les (they) in French, which appears in the first sentence of the text. During the rather long pause of 1 minute, 1 second in Translog segment 2, we see that Christine makes an interesting comment on an association to a Norwegian book she once read about good manners.

(12) Christine's Translog data and TAP file:

\begin{tabular}{|c|c|c|}
\hline Christine's Translog data & Christine's TAP & Translation into English \\
\hline 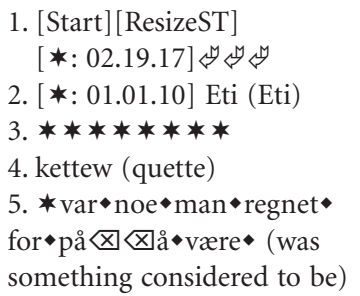 & $\begin{array}{l}\text { Hva er det den boken til } \\
\text { Randi Brattholm het? Var det } \\
\text { ikke Etikette? Skikk og bruk? } \\
\text { Nei, skikk og bruk, det blir litt } \\
\text { for... Jeg kan jo blande litt, } \\
\text { bruke gode manerer og litt... }\end{array}$ & $\begin{array}{l}\text { What was the name of that } \\
\text { book by Randi Brattholm? } \\
\text { Wasn't it Etikette? Skikk og } \\
\text { bruk (code of conduct)? No, } \\
\text { code of conduct, that makes it } \\
\text { a little too... What I can do is } \\
\text { blend them a little, use good } \\
\text { manners and then... }\end{array}$ \\
\hline
\end{tabular}




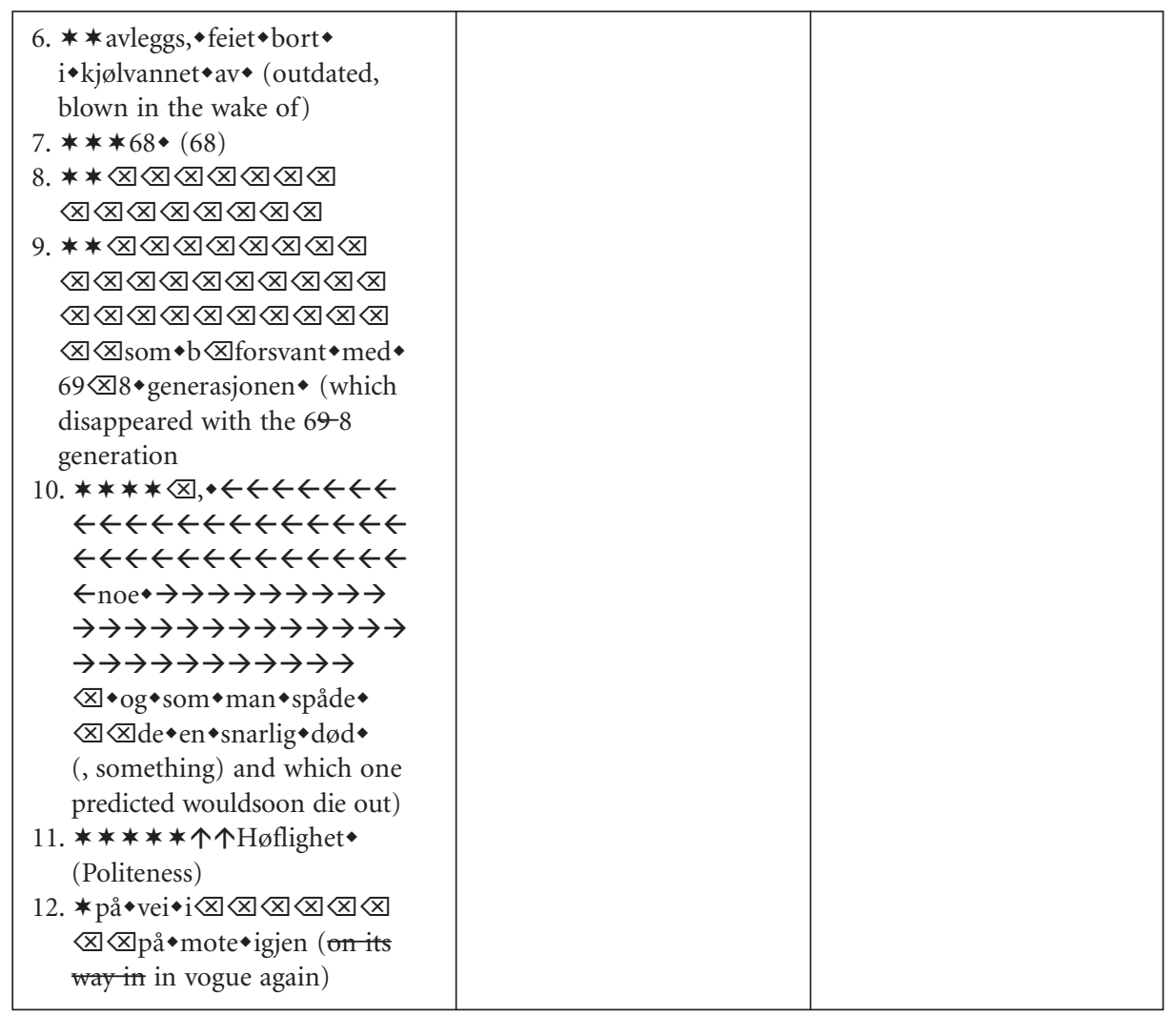

The Translogged passage containing the segments 2-12 can be read as follows:

(13) Etiquette was something considered to be outdated, something which disappeared with the 68 generation and which one predicted would soon die out Politeness in vogue again

Although Christine does not verbalize the rest of her thoughts, we see from her last TAP comment in (12): "What I can do is blend them a little, use good manners and then..." that she is aware that the term 'good manners,' which is the topic of the text, appears under different linguistic forms throughout the text, and that she will consequently have to resort to different synonyms in her translation. When the acronym BSAM appears, we remember she made a declarative statement about rejecting the corresponding acronym in the target language: "I don't think there's any point in keeping it" (cf. her TAP comment in (9) above). Instead she settles for a solution which is a reactivation of one of the three contextual synonyms she had originally thought out to translate bonnes manières in the title. In other words she draws on the cognitive context when making this clear link to an earlier passage in the text which represents the same idea under different words.

Translog segments 11 and 12 show that Christine returns to the translation of the title in the middle of her translation of the first sentence in the text. (The reason underlying her choice of the word høflighet 'politeness' in the title is accounted for in Rydning 2004.) 
Let us now turn to Anne's process data. Anne's TAP and Translog file give us an idea of the reason underlying her syntactic rearrangement of the metonymic elements as compared to the original.

(14) Anne's Translog data and TAP file:

\begin{tabular}{|c|c|c|}
\hline Anne's Translog data & ine's TAP & Translation into English \\
\hline 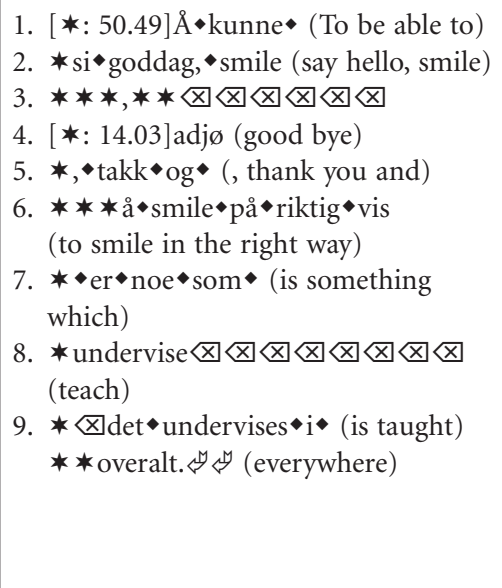 & $\begin{array}{l}\text { BSAM, ja, det var verre, } \\
\text { (myser) (pause) Det har jo } \\
\text { ikke noe sånn... tilsvarende } \\
\text { (kremter)... på norsk da } \\
\text { akkurat. Men da må jeg jo } \\
\text { nesten bare.... lage en } \\
\text { périphrase for å formidle.. } \\
\text { hva de mener (skriver) } \\
\text { (pause) (myser). Skal vi se, } \\
\text { her er det jo ... å kunne si } \\
\text { god dag... da får jeg ta de } \\
\text { tingene som passer } \\
\text { sammen da, og sette smile } \\
\text { til slutt: å si goddag } \\
\text { (skriver) }\end{array}$ & $\begin{array}{l}\text { BSAM, well, that's worse. } \\
\text { (frowns) (pauses) But } \\
\text { then there is no such... } \\
\text { corresponding (coughs } \\
\text { slightly)... in Norwegian. } \\
\text { I'll then just have to ... } \\
\text { make a périphrase to } \\
\text { convey... what they mean } \\
\text { (writes) (pauses)(frowns). } \\
\text { Let's see, here we have ... } \\
\text { to be able to say good } \\
\text { morning ... well I'll have } \\
\text { to take the things that go } \\
\text { together, and then put } \\
\text { smile at the end: to say } \\
\text { good morning (writes) }\end{array}$ \\
\hline
\end{tabular}

The long Translog pause of 50.49 seconds in Translog segment 1 is a clear indication of a problem at hand. Her corresponding TAP indicates that she is aware there is no lexicalized acronym corresponding to BSAM in Norwegian. If we now look at her Translog file again, the two first segments show that her first reaction was to transcode the salient aspects contained in the original metonymic expression. But then apparently concerned about this solution's lack of grammaticality, she decides to rearrange the elements in a periphrasis and chooses to coordinate two infinitive clauses. Anne does not make any comment on the reason why she decided to add the prepositional syntagm 'in the right way.' This solution has most probably come to her in a spontaneous and effortless manner, as can be seen from the very short pause of only 3 seconds in Translog segment 6, as a result of her interpretation of the sense. As Jean Delisle has observed, a well understood idea is usually re-expressed with ease:

Il arrive que la découverte d'une équivalence se produise plus ou moins spontanément. Dans ces moments "d'inspiration," le raccordement des concepts est instantané. Il résulte d'une compréhension parfaite des idées à rendre alliée à une disponibilibité totale des moyens linguistiques pour les exprimer. Ce qui a été bien conçu est réexprimé aisément. (Delisle 1980.: 82)

As we will see the BT-model yields a plausible explanation to this addition of hers.

\section{A BT-account of sense construction in translation}

Let us now turn to the BT-model to account for how the sense in the French utterance (7) has been perceived by Anne and Christine. Their translations can be taken as indicators as to how conceptual structure from two different domains have been integrated in the rendering of the sense in their TT. We shall start with Anne. 
The BT-structure in Anne's solution can be represented as follows: In input space 1 we have the domain of courteous behavior cued by the four marks of courtesy. In input space 2 we have the domain of skills, i.e. how to do things appropriately, cued by the expression 'in the right way.' The generic space can be represented as behavioral know-how. Partial structure from the two input spaces is projected into the blend yielding the sense: good manners/breeding.

(15) A BT-account of Anne's solution:
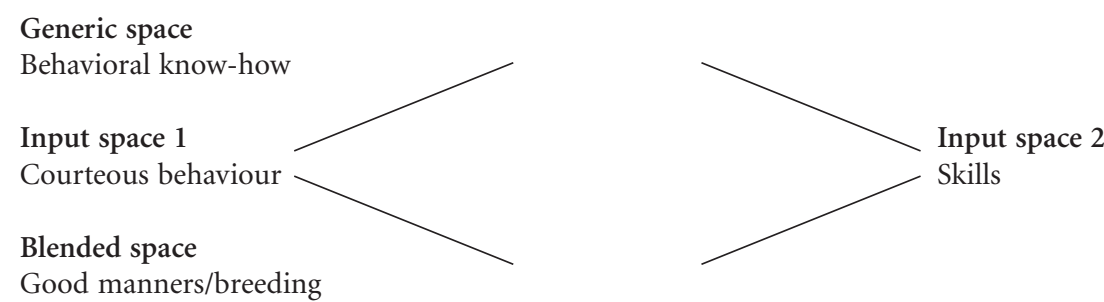

Anne's addition of the syntagm 'in the right way, which at first sight could look fortuitous, finds a plausible explanation in the BT-model. Her solution can be seen as a reflection of the way she has understood the sense in the French original. Anne has resorted to the device of making explicit in her TT a notion which was implicitly contained in the ST. Although her solution used to convey the abstract mental picture of good manners does not coincide fully with the expression used in the original, both expressions convey the same sense.

The reason I chose to give a BT-account of Anne's solution first, is that it will help us understand the network projections underlying Christine's solution.

(16) A BT-account of Christine's solution:
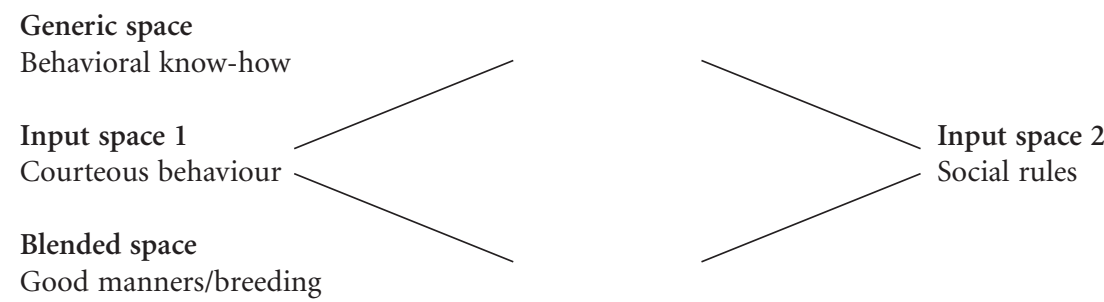

Good manners/breeding

In input 1 we have the domain of courteous behaviour cued by the four marks of courtesy in the French original. In input space 2 we have the domain of mastering social rules, cued by the expression skikk og bruk 'code of conduct.' This expression implies a set of rules on how to behave in the right manner in different social settings. The generic space can be represented in the same manner as for Anne, as behavioral know-how. The projection of structure from these two inputs in the blend yields the same sense as in the French original, that of good manners/breeding.

\section{Conclusion}

I have tried to show through sample examples that the construction of sense is a mental activity which can be accounted for in terms of blending. The BT-model 
shows that words act merely as cues for the sense we are prompted to construct. They are triggers to our imagination, where we project concepts into other concepts. The true relation holding between the original sense and the translators' creative construals of sense appears to be of a conceptual nature.

A basic argument for putting forward a translation theory with an essentially cognitive grounding, is that sense construction is one of the cornerstones of cognitive linguistics. Compared to other language processes, translation has the advantage of dealing with sense construction twice, both in the phase of understanding and in that of reformulating what has been understood. It therefore offers researchers within cognitive science an exceptional stand into one of the most intricate aspects of the human mind: how to make sense. On the other hand, BT appears to offer translation theorists a general model of sense construction which enables them to account for the cognitive mechanisms underlying sense construction which are central in translation.

\section{NOTES}

1. I have dealt elsewhere with the translation of metaphors. See Rydning 2004 forthcoming.

\section{REFERENCES}

Barcelona, A. (2000): Introduction. The Cognitive Theory of Metaphor and Metonymy, in A. Barcelona (ed.), Metaphor and Metonymy at the Crossroads. A Cognitive Perspectiv, Berlin/ New York, Mouton de Gruyter, p. 1-28.

Blank, A. (1993): Polysemie und semantische Relationen in Lexicon, in W. Börner, K. Vogel (eds.), Wortschatz und Fremdsprachernerwerb, Bocum: AKS, p. 22-56.

Coulson, S. \& T. OAkley (2003): Metonymy and Conceptual Blending, in K-U. Panther and L. L. Thornberg (Eds.), Metonymy and Pragmatic Inferencing, Amsterdam, John L. Benjamins, p. 59-88

Delisle, J. (1980): L'analyse du discours comme méthode de traduction, Ottawa, Éditions de l'Université d'Ottawa.

Delisle, J. (1993): La traduction raisonnée, Ottawa, Éditions de l'Université d'Ottawa.

Dirven, R. and R. Pörings (eds.) (2002): Metaphor and Metonymy in Comparison and Contrast, Berlin, Mouton de Gruyter.

Fauconnier, G. (1994): Mental Spaces, New York, Cambridge University Press.

Fauconnier, G. \& M. Turner (1996): Blending as a Central Process of Grammar, in A. Goldberg (ed.), Conceptual Structure, Discourse, and Language, Stanford University, Centre for the Study of Language and Information (CSLI), p. 113-130.

Fauconnier, G. (1997): Mappings in Thought and Language, Cambridge, Cambridge University Press.

Fauconnier, G. and Turner, M. (1998): Conceptual Integration Networks, Cognitive Science, 22, p. 133-187.

Fauconnier, G. and Turner, M. (1999): Metonymy and Conceptual Integration, in Panther and Radden (eds.), Metonymy in Language and Thought, Amsterdam and Philadelphia, John Benjamins, p. 77-90.

Fauconnier, G. and M. Turner (2000): Metaphor, Metonymy, and Binding, in A. Barcelona (ed.), Metaphor and Metonymy at the Crossroads. A Cognitive Perspective, Berlin/New York, Mouton de Gruyter, p. 133-145.

Fauconnier, G. and M. Turner (2002): The Way We Think: Conceptual Blending and the Mind's Hidden Complexities, New York, Basic Books.

Gibbs, R. W. (1994): The Poetics of Mind, Cambridge, Cambridge University Press. 
Gibbs, R.W. (1999): Speaking and Thinking with Metonymy, in Panther and Radden (eds.), Metonymy in Language and Thought. Amsterdam/Philadelphia, John Benjamins, p. 61-76.

Grady, J.E., Oakley, T. and S. Coulson (1999): Conceptual Blending and Metaphor, in G. Steene and R. Gibbs (eds.), Metaphor in Cognitive Linguistics. Amsterdam/Philadelphia, John Benjamins, p. 101-124.

Grady, J.E., Oakley, T. and S. Coulson (1999): Blending and Metaphor, in R.W. Gibbs and G.J. Steen (eds.), Metaphor in Cognitive Linguistics. Amsterdam/Philadelphia, John Benjamins.

Hurtado, A. A. (1989): La notion de fidélité en traduction, Paris, Didier Érudition, Cahier de traductologie 5.

Lakoff, G. and M. Johnsen (1980): Metaphors We Live By, Chicago/London, The University of Chicago Press.

Lakoff, G. and M. Turner (1989): More than Cool Reason. A Field Guide to Poetic Metaphor, Chicago/London, The University of Chicago Press.

Laplace, C. (1994): Théorie du langage et théorie de la traduction: les concepts-clefs de trois auteurs: Kade (Leipzig), Coseriu (Tübingen), Seleskovitch (Paris), Paris, Didier Érudition.

Langacker, R. (1987): Foundations of Cognitive Grammar, Vol 1. Theoretical Prerequisite, Stanford, Stanford University Press.

LANGacker, R. (1991): Foundations of Cognitive Grammar, Vol 2. Descriptive Application, Stanford, Stanford University Press.

LANGACKer, R. (1991): Concept, Image, and Symbol. The Cognitive Basis of Grammar, Berlin/New York, Mouton de Gruyter.

LANGaCKer, R. (1999): Grammar and Conceptualization, Berlin, Walter de Gruyter.

Lederer, M. (1976): Synecdoque et traduction, in Seleskovitch, D. (ed.), Traduire les idées et les mots. Paris: ELA 24, Didier.

Lederer, M. (ed.) (1990): Études traductologiques en hommage à Danica Seleskovitch, Paris, Lettres modernes Minard.

Panther, K.U. and Radden, G. (1999): Towards a Theory of Metonymy, in Panther and Radden (eds.), Metonymy in Language and Thought. Amsterdam/Philadelphia, John Benjamins Publishing Company, p. 17-59.

Panther, K.U. and Panther, G. (1999): Metonymy in Language and Thought, Amsterdam/Philadelphia, John Benjamins Publishing Company.

Ruiz de Mendoza Ibánez, F.J. (2000): The Role of Mappings and Domains in Understanding Metonymy, in A. Barcelona (ed.), Metaphor and Metonymy at the Crossroads. A Cognitive Perspectiv, Berlin/New York, Mouton de Gruyter, p. 109-132.

Rydning, A.F. (2004): (forthcoming) Étude de l'effort cognitif du traducteur lié à la reformulation de métaphores, in M. Lederer. \& F. IsraëL (eds.), La traduction interprétative de la traduction: Regards croisés, Paris, Lettres modernes Minard.

Rydning, A.F. (2003): La métonymie conceptuelle, in H. Dørum (ed.), Romansk Forum Nr. 17. Oslo, Universitetet i Oslo, p. 71-84.

Rydning, A.F. (2003): Kreativitetsaspektet i lys av to kognitive teorier: CMT og BT, in H. DøRum (ed.), Romansk Forum Nr. 18. Oslo: Universitetet i Oslo, p. 21-41.

Seleskovitch, D. (1968): L'interprète dans les conférences internationales, Paris, Lettres modernes Minard.

Seleskovitch, D. (1975): Langage, langues et mémoire, Paris, Lettres modernes Minard.

Seleskovitch, D. et M. Lederer (1984): Interpréter pour traduire, Paris, Didier Erudition.

Seleskovitch, D. et Lederer, M. (1989): Pédagogie raisonnée de l'interprétation, Paris, Didier Erudition Opoce.

Turner, M., \& Fauconnier (1999): A Mechanism of Creativity, Poetics Today, 20, p. 397-418. 


\section{APPENDIX: FRENCH ORIGINAL TEXT}

\section{Le retour des bonnes manières}

On les croyait désuètes, balayées par l'ouragan post-soixante-huitard, promises à une mort imminente par la recrudescence des incivilités. On les imaginait figées, tout juste bonnes à illustrer les manuels d'éducation pour jeunes filles de bonne famille. Erreur. Liftées, épurées, les bonnes manières sont à nouveau plébiscitées par les Français. Les bonnes manières sont un signe d'intégration. Mais elles restent aussi, plus sournoisement, un mode de tri social. Raison de plus pour maîtriser les codes. Les entreprises exigent aujourd'hui de leurs employés qu'ils sachent communiquer. Le "BSAM" (bonjour-sourire-au revoir-merci) est enseigné partout. Conseillère en image personnelle, Hélène Choumiloff veille au grain. Ses "élèves" sont des cadres de sexe masculin de plus de 40 ans. Leur objectif: éviter les gaffes au cours des dîners d'affaires. "Beaucoup de mes clients se sont faits à la force du poignet. C'est l'ascension sociale qui crée la gêne," constate la conseillère. Pendant les exercices, dans la rue ou au restaurant, elle traque les failles. L'apprentissage peut durer trois mois. Les élèves sont très motivés. S'il est désormais bien vu de laisser au placard cravate et costume trois pièces le vendredi, nul ne tolère, désormais, les infractions au code de bonne conduite.

Laurence Albert, Extrait de l'Express - Société, janvier 2001. 